\title{
PEMETAAN AWAL POTENSI ENERGI LAUT DI PANTAI SELATAN PULAU JAWA DENGAN PEMODELAN HIDRODINAMIKA
}

\author{
Danar Guruh Pratomo ${ }^{1}$, Hanna Anie Sharlene Rayitno Soebari ${ }^{2}$ \\ 1,2Departemen Teknik Geomatika FTSLK-ITS, Kampus ITS Sukolilo, Surabaya, 60111 \\ e-mail: ${ }^{1}$ guruh@geodesy.its.ac.id, ${ }^{2}$ hannarajitno@gmail.com
}

\begin{abstract}
Abstrak
Sumber energi terbarukan yang dapat dimanfaatkan dari laut adalah arus laut, pasang surut, gradien temperatur laut (ocean thermal energy conversion), dan gelombang laut. Penelitian ini menganalisis kecepatan arus, ketinggian gelombang, dan rentang pasang surut yang dapat dikonversi menjadi energi potensial listrik di tiap $\pm 20 \mathrm{~km}$ segmen sepanjang garis pantai. Model hidrodinamika 3D penelitian ini menggunakan mesh berbentuk structured grid dari data garis pantai dan batimetri. Sedangakan, data pasang surut dan data angin sebagai input parameter pemodelan. Data pasang surut dari stasiun pasut BIG digunakan untuk memvalidasi hasil model. Berdasarkan pengolahan dan analisis data 43 titik pengamatan, pantai selatan Pulau Jawa tidak memiliki potensi energi gelombang laut dikarenakan ketinggian gelombang yang tidak memenuhi nilai minimum yang dibutuhkan. Namun, potensi energi pasang surut menghasilkan energi yang lebih besar dan lebih merata di sepanjang pesisir dibandingkan dengan potensi energi arus laut. Peninjauan akses jalan di sekitar wilayah pesisir menghasilkan 19 titik potensi energi laut di selatan Pulau Jawa. Nilai rata-rata estimasi energi pasang surut yang dihasilkan pada bulan Februari dan Oktober masing-masing sebesar $560468,327 \mathrm{~kW}$ dan 373867,1891 kW.
\end{abstract}

Kata kunci: Model Hidrodinamika 3D, Kecepatan Arus, Rentang Pasut, Ketinggian Gelombang, Estimasi Daya

\begin{abstract}
Ocean potential renewable energy sources can be utilized from currents, tides, thermal energy conversion, and wave. This study analyzed current velocity, wave height, and tidal range that can be converted to electrical potential energy in every $\pm 20 \mathrm{~km}$ segment along the coastline.Three-dimensional hydrodinamics model in this study used structured grid mesh from coastline, bathymetry data, tidal data, wind data, and rainfall information to define the model month selection. Tidal data from Geospatial Information Agency were used to validate the model. Due to wave height, the ocean potential energy from the wave does not meet the minimum value requirement based on the model processing and data analysis of 43 observation points. However, the potential of tidal energy generates greater and more equitable energy along the coast compared to the potential of ocean currents. There are 19 potential points for ocean renewable energy on southern coastal of Java reviewed from the road access around the coast. The average estimated power from tidal in February and October were $560468.327 \mathrm{~kW}$ and $373867.189 \mathrm{~kW}$, respectively.
\end{abstract}

Keywords: 3D Hydrodinamcs Model, Current Velocity, Tidal Range, Wave Height, Power Estimated 


\section{PENDAHULUAN}

Berdasarkan Peraturan Presiden Republik Indonesia Nomor 5 Tahun 2006 tentang Kebijakan Energi Nasional bahwa negara menjamin pasokan energi dalam negeri dan untuk pembangunan yang berkelanjutan ${ }^{[1]}$. Energi listrik merupakan alat penunjang aspek kehidupan dan pembangunan nasional dalam peningkatan mutu taraf hidup bangsa Indonesia. Sumber energi konvensional berupa energi fosil yang merupakan sumber energi utama Indonesia, sudah semakin terbatas cadangannya sehingga dibutuhkan alternatif lain sebagai tenaga pembangkit listrik.

Salah satu langkah kebijakan Kementerian Energi dan Sumber Daya Mineral (KESDM) dalam menjawab isu nasional mengenai energi dengan diversifikasi energi adalah penganekaragaman penyediaan dan pemanfaatan berbagai sumber energi baru, salah satunya adalah sumber energi kelautan (DESDM 2005). Dasar pengembangan kelautan telah diatur dalam Undang Undang Nomor 17 Tahun 2007 tentang Rencana Jangka Panjang Nasional (RJPN). Kenyataannya, rencana ini masih belum dapat terealisasikan karena beberapa hal, diantaranya belum tersedianya informasi potensi energi kelautan yang secara ekonomis dapat dimanfaatkan untuk pembangkit tenaga listrik (Mukhtasor 2011).

Dengan kondisi topografi Indonesia yang merupakan negara kepulauan terbesar dengan total luas lautan hampir 6 juta $\mathrm{km}^{2}$ serta memiliki panjang garis pantai kurang lebih sekitar 81.000 kilometer. Indonesia memiliki potensi yang sangat besar terhadap pengembangan energi arus, gelombang, pasang surut air laut dalam pembangunan energi terbarukan sebagai upaya penting dalam mengeksplorasi sumber energi non konvensional dari laut.

Penelitian ini dimaksudkan untuk mengetahui lokasi dengan masing-masing tipe energi laut berupa pola arus, gelombang, dan pasang surut yang dimiliki dengan memanfaatkan model hidrodinamika 3D di Pantai Selatan Jawa. Pantai Selatan Jawa memiliki kondisi pasang surut dengan tipe campuran dominan semidiurnal (Purba 2014). Selain itu, Pantai Selatan Jawa memiliki gelombang dan arus besar karena wilayahnya berbatasan langsung dengan Samudera Hindia. Sehingga dengan mempertimbangkan aspek tersebut maka pemilihan lokasi penelitian berada di kawasan Pantai Selatan Jawa. Pemanfaatan energi laut sebagai tenaga pembangkit listrik diharapkan dapat diimplementasikan dengan baik di Indonesia selain hemat dalam perawatan, energi laut juga meminimalisir kerusakan lingkungan dibandingkan penggunaan energi fosil.

\section{METODE}

\section{Lokasi Penelitian}

Lokasi penelitian ini berada di kawasan Pantai Selatan Jawa yang secara geografis terletak pada $6^{\circ} 45^{\prime} 20,08^{\prime \prime}$ - $10^{\circ} 52^{\prime} 8,95^{\prime \prime}$ LS dan $104^{\circ} 33,28^{\prime \prime}$ $114^{\circ} 38^{\prime} 40,39^{\prime \prime}$ BT.

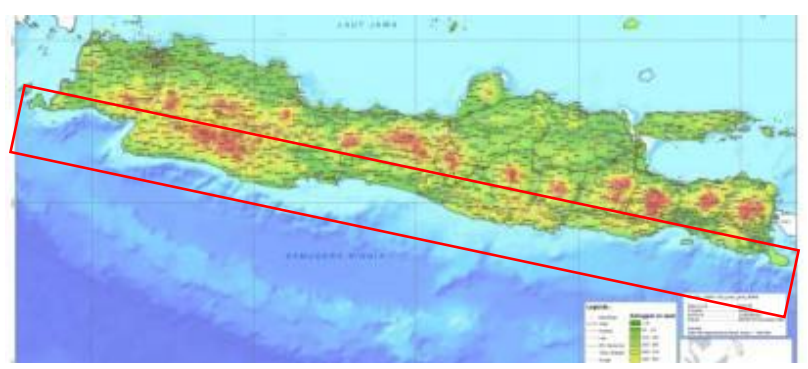

Gambar 1 Peta Pulau Jawa (BNPB, 2009)

\section{Data}

Data yang digunakan dalam penelitian ini adalah:

a. Data batimetri pantai selatan Jawa tahun 2017 didapatkan dari General Bathymetric Chart of the Ocean (GEBCO).

b. Data garis pantai tahun 2017 dari Coastal Extraction untuk pembuatan grid dari Indonesia Geospasial Portal.

c. Data kecepatan dan arah angin dari National Oceanic and Atmospheric Administration (NOAA) sebagai data input parameter pemodelan.

d. Data ketinggian gelombang, serta kecepatan dan arah arus tahun 2017 daerah pantai selatan Jawa yang dikeluarkan oleh BMKG (Badan Meteorologi, Klimatologi dan Geofisika) untuk digunakan sebagai validasi model.

e. Data pasang surut daerah pantai selatan Jawa tahun 2017 dari stasiun pasut BIG (Badan Informasi Geospasial) sebagai data input parameter pemodelan. 


\section{Tahap Persiapan Penelitian}

Tahap persiapan meliputi mencari dan mempelajari berbagai studi literatur yang terkait dengan penelitian. Adapun beberapa fokus studi literatur yang diperlukan dalam menunjang pelaksanaan penelitian ini. Pertama mengenai pemodelan arus. Kedua mengenai persamaan konversi energi kinetik laut berupa pasang surut, arus, dan gelombang laut menjadi energi potensial listrik. Terakhir, mengenai software yang digunakan untuk membantu proses pemodelan yaitu perangkat lunak pengolahan model numerik Delft3D. Software ini digunakan untuk proses pemodelan arus dan gelombang, yang didalamnya mencakup pembuatan grid, interpolasi kedalaman, mesh, pemodelan hidrodinamika area penelitian. Modul yang digunakan adalah modul RGFGRID, QUICKIN, FLOW, WAVE, QUICKPLOT, dan GPP. Adapun persamaan yang digunakan dalam proses pemodelan adalah model aliran arus dengan persamaan hidrodinamika.

Dalam tahap ini dilakukan pengambilan data meliputi data sekunder yang nantinya digunakan dalam proses pembuatan model. Data-data yang diperlukan antara lain data batimetri yang diunduh dari http://www.bodc. ac.uk/data/hosted_data_systems/gebco_gridded _bathymetry_data/; data kecepatan dan arah arus, serta data ketinggian gelombang dari Badan Meteorologi, Klimatologi, dan Geofisika (BMKG); data pengamatan dan prediksi pasang surut dari stasiun pasut dan web http://www.tides.big.go. id; data garis pantai yang diunduh dari http:// www.tanahair.indonesia.go.id/portal-web.

\section{Tahap Pengolahan Data dan Analisis Penelitian}

Pada tahap awal pengolahan data dilakukan konversi terhadap data garis pantai, data pasang surut, dan data batimetri. Konversi data garis pantai yang telah di download dalam format *.shp ke dalam format *.Idb dan *.pol dilakukan menggunakan software Global Mapper 18. Proyeksi koordinat data garis pantai dari koordinat WGS ke koordinat UTM 49 S juga dilakukan pada tahap ini. Data ini nantinya akan digunakan untuk pembuatan batas area pemodelan. Konversi data batimetri dalam format netCDF (*.nc) ke dalam format *.xyz juga dilakukan pada tahap ini.

Selanjutnya data elevasi pengamatan pasang surut yang didapatkan dari BIG diolah dengan metode least square adjustment agar sesuai dengan nilai water level (MSL) masingmasing lokasi stasiun pasang surut. Nilai pengamatan pasang surut terhadap MSL ini dipakai sebagai nilai water level input paremeter pemodelan yang membangkitan arus dari pasang surut. Penghitungan nilai acuan datum vertikal MSL masing-masing stasiun pasang surut dapat menggunakan software MATLAB R2014a.

Gridding kemudian dilakukan untuk membuat grid, memodifikasi dan memvisualisasikan orthogonal area pemodelan. Proses ini dilakukan dengan menggunakan modul RGFGRID yang tersedia di Delft3D. Grid yang dibuat memiliki bentuk structured grid berupa rectangular grid, sehingga menu yang digunakan pada Operations adalah Create Rectangular or Circular Grid. Grid dibuat dengan ukuran 2.500 x 2.500 m dengan posisi grid berhimpit dengan garis pantai. Data garis pantai sebagai batas area pemodelan kemudian dimasukkan menggunakan Import boundary data. Sehingga, diperoleh grid sesuai daerah simulasi pemodelan (wilayah perairan), dengan data garis pantai berfungsi sebagai pemisah antara daratan dengan perairan. File grid ini kemudian disimpan dalam format *.grd dan *.enc.

Interpolasi kedalaman adalah proses memasukkan nilai kedalaman ke tiap grid yang sebelumnya telah dibentuk melalui proses gridding. Sehingga diperoleh data mesh (grid dengan informasi kedalaman) untuk keperluan proses pemodelan selanjutnya. Proses ini dilakukan dengan menggunakan modul QUICKIN yang tersedia di Delft3D. Import file grid dan data kedalaman yang telah memiliki acuan datum vertikal MSL. Proses interpolasi kedalaman dilakukan dengan menggunakan metode Triangulation Interpolation pada menu Operations. Sehingga akan dihasilkan data kedalaman hasil interpolasi yang tersimpan dalam format *.dep.

Dengan penggabungan data kedalaman pada grid yang telah dibuat, maka terbentuklah model domain atau mesh. acuan data mesh yang telah dihasilkan, dilakukan pemodelan arus yang dibangkitkan oleh pasang surut dan angin yang disusun pada time series, nilai gravitasi, densitas air laut, dan densitas udara sebagai parameter pemodelan. Proses input paramater menggunakan modul Flow input yang terbagi kedalam input: domain, timeframe, processes, initial conditional, boundaries, physical parameters, numerical 
parameters, dan monitoring. Parameterparameter tersebut merupakan aspek yang mempengaruhi proses pergerakan arus. Sehingga akan dihasilkan model arus area penelitian berdasarkan faktor-faktor yang mempengaruhinya.

Input parameter yang digunakan pada modul Flow input juga digunakan pada modul Wave input. Hal ini dilakukan dengan mencentang kotak pilihan hydrodinamics, dan mengatur agar hasil running Flow input, seperti timeframe, waterlevel, current, bathymetry, dan physical parameters (wind, constants) dapat digunakan sebagai aspek yang mempengaruhi proses pembentukan gelombang. Sehingga akan dihasilkan model gelombang area penelitian berdasarkan faktor-faktor yang mempengaruhinya.

Simulasi pemodelan ini dilakukan pada bulan Februari dengan lama simulasi 28 hari dan bulan Oktober dengan lama simulasi selama 31 hari. Hal ini dilakukan atas dasar pernytaan Badan Meteorologi Klimatologi dan Geofisika (BMKG) pada koran Republika, dimana musim hujan tahun 2017 secara umum mulai terjadi pada akhir Oktober hingga November dan puncak musim hujan akan diprediksi terjadi pada Desember 2017 hingga Februari 2018 (Republika 2017).

Hasil simulasi model arus dan gelombang kemudian perlu dilakukan proses validasi kualitas data pasang surut. Hal ini dilakukan terhadap hasil data pengamatan dengan hasil data pemodelan. Tingkat kesalahan (error) dari data model dibandingkan dengan data lapangan dilakukan perhitungan root mean square error (RMSE) dan mean absolute error (MAE). Nilai RMSE merupakan rata-rata besar kesalahan pada suatu sampel data, sedangkan MAE adalah ratarata besar kesalahan tanpa memperhitungkan arah kesalahannya. Bersama-sama, nilai RMSE dan MAE menunjukkan variasi kesalahan yang terjadi pada sampel data tersebut, RMSE selalu lebih besar atau sama dengan MAE. Semakin besar beda antara RMSE dan MAE, maka semakin besar pula variasi / perbedaan masing-masing kesalahan pada sampel yang dihitung (Khotimah 2012). Rumusan RMSE dan MAE yang digunakan adalah sebagai berikut:

$$
\text { RMSE }=\sqrt{\frac{\sum_{i=1}^{n}\left(x_{\text {obs }, i}-x_{\text {model } i j}\right)^{2}}{n}}
$$

$$
M A E=\frac{1}{n} \sum_{i=1}^{n}\left|y_{i}-\hat{y}_{i}\right|
$$

dimana,

$$
\begin{array}{lll}
y_{\mathrm{i}} & : \text { Data lapangan } \\
\hat{y}_{\mathrm{i}} & : \text { Data hasil pemodelan } \\
x_{\text {obs ij }} & : \text { Data lapangan } \\
x_{\text {model,ji }} & : \text { Data hasil pemodelan } \\
n & : \text { Jumlah data }
\end{array}
$$

Model akan dapat digunakan pada tahap selanjutnya jika tingkat kesalahan (error) yang dihasilkan masuk pada rentang 0,00-0,299 $\mathrm{m}$ dan tergolong kecil (Khotimah 2012). Semakin kecil nilai kesalahan (error) yang dihasilkan menyatakan semakin dekat nilai pemodelan dengan nilai sebenarnya (Darmawan 2005).

Pada tahap analisis dilakukan analisis terhadap pola arus dan gelombang, identifikasi lokasi setiap segmen $( \pm 20 \mathrm{~km})$ di sepanjang garis pantai, estimasi besaran energi listrik yang dihasilkan dari ketiga tipe energi laut pada lokasi tersebut.

Langkah akhir yaitu pembuatan hasil akhir dari simulasi model arus dan gelombang yang dibuat kedalam sebuah video sehingga tersaji lebih menarik dan peta lokasi potensial energi laut yang dibuat menggunakan software ArcGIS 10.3 untuk layouting lengkap dengan estimasi besaran energi listrik yang dihasilkan.

\section{Tahap Akhir Penelitian}

Tahap akhir dari penelitian ini adalah penyusunan laporan mengenai penelitian tentang pemodelan arus dan gelombang yang dapat dijadikan sebagai acuan pembangunan pembangkit listrik energi laut. Dalam hal ini khususnya di kawasan pantai selatan Pulau Jawa.

\section{HASIL DAN PEMBAHASAN}

\section{Pendefinisian Batas}

Langkah awal dalam pembuatan bidang model (grid) adalah dengan mendefinisikan batas area pemodelan yang diwakilkan dengan garis pantai. Dalam penelitian ini datum vertikal yang digunakan dalam pembuatan model adalah MSL (Mean Sea Level) atau kedudukan muka air rata-rata. Garis pantai yang digunakan untuk mendefinisikan batas model diperoleh dari laman Indonesia Geospasial Portal (http://tanahair.indonesia.go.id/portalweb).

Wilayah penelitian berjarak $35 \mathrm{~km}$ atau 18,886 mil laut dari garis pantai terluar. Untuk 
dapat digunakan dalam proses selanjutnya, diperlukan penyesuaian format data masukan yang dapat diterima oleh software Delft3D yakni polygon (*.pol). Pada Gambar 2 ditampilkan gambaran batas model yang digunakan dalam penelitian ini.

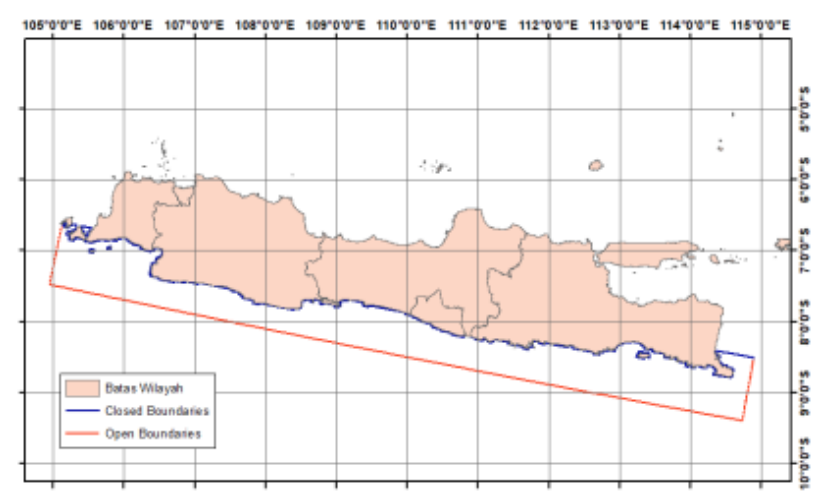

Gambar 2. Batas Model Garis Pantai

\section{Desain Model Grid}

Setelah pendefinisian batas, langkah selanjutnya dalam pembuatan bidang model adalah pembuatan jaring-jaring atau bidang jala yang akan mewakili area bidang model yang kemudian disebut sebagai grid. Grid yang dibuat adalah tipe structured grid, dengan model berbentuk kotak. Bentuk grid ini digunakan untuk menggambarkan atau mewakili bentuk penampang wilayah penelitian ke dalam sebuah model. Grid yang dihasilkan memiliki node grid sejumlah $441 \times 41$.

Pembuatan model grid menggunakan modul RGFGRID yang dimiliki oleh Delft3D. Sehingga dalam modul ini dapat dilakukan pembuatan, modifikasi, dan visualisasi grid. Model Grid merupakan aspek penting dalam proses pemodelan hidrodinamika dan transpor sedimen. Bentuk, ukuran dan luas model grid selalu bergantung pada studi kasus lokasi pembuatan model. Grid dibuat sedemikian rupa, untuk dapat mewakili area studi. Gambar 3. menunjukkan bentuk grid yang telah disesuaikan dengan area studi.

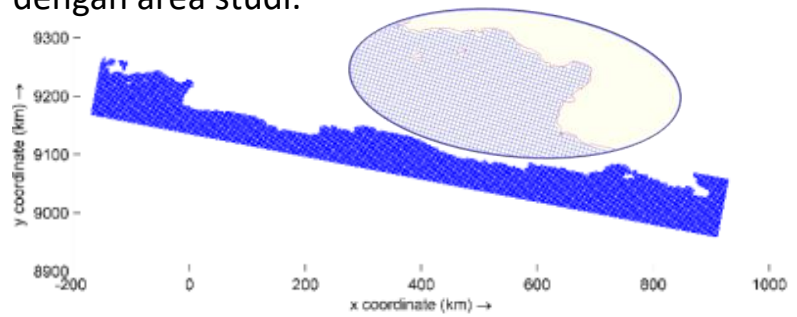

Gambar 3 Model Grid

\section{Model Domain}

Salah satu data penting dalam pembuatan model domain adalah informasi nilai kedalaman pada perairan area penelitian. Gambar 4 menampilkan sebaran titik-titik kedalaman yang digunakan dalam penelitian ini.

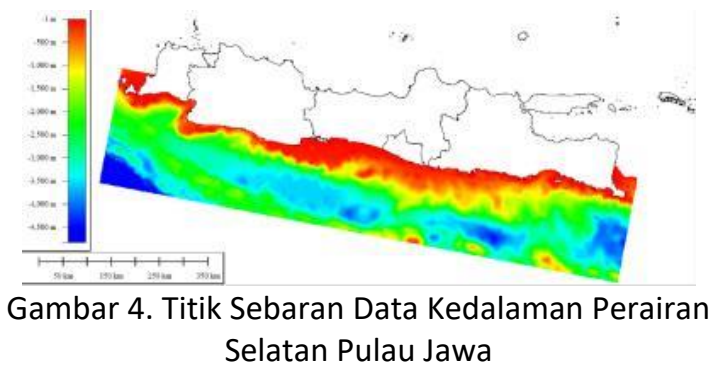

Titik-titik yang tersebar di dalam batas model adalah titik sebaran nilai kedalaman yang telah bereferensi pada referensi vertikal MSL (Mean Sea Level). Informasi nilai kedalaman dari titik sebaran ditunjukkan dengan diagram warna.

Interpolasi kedalaman merupakan tahap yang dilakukan untuk mendefinisikan nilai kedalaman kedalam masing-masing grid. Sehingga fungsi proses ini digunakan untuk menentukan kedalaman titik-titik cell grid pada masing-masing grid terhadap data kedalaman batimetri.

Dalam proses interpolasi kedalaman menggunakan metode triangular interpolation. Metode triangular interpolation merupakan metode sederhana dan banyak digunakan dalam interpolasi data. Algoritma ini menciptakan segitiga/triangulasi dengan menarik garis antar titik data. Setiap segitiga mendefinisikan sebuah permukaan di atas grid yang berada di dalam segitiga tersebut. Triangulasi dengan interpolasi linier bekerja paling baik bila data yang ada merata di atas area grid (Sutrisno dan Isjudarto 2016). Hasil interpolasi menunjukkan kedalaman dari bidang model yang ditampilkan pada Gambar 5 sebagai berikut:

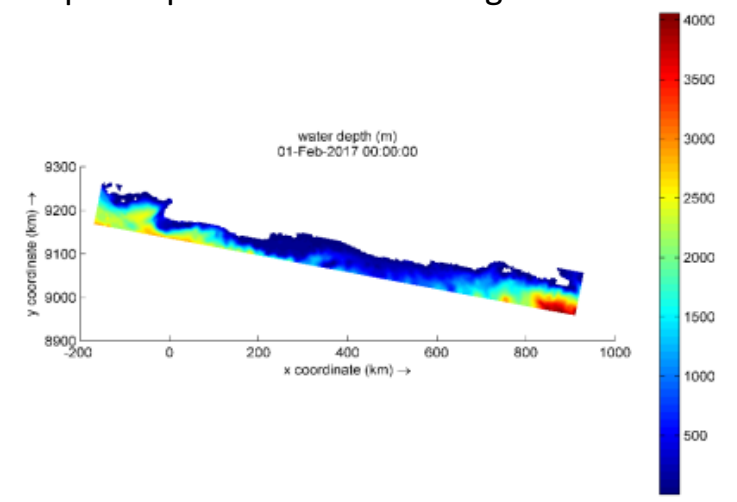

Gambar 5. Hasil Interpolasi Kedalaman Bidang Model 
Pada gambar hasil interpolasi kedalaman, informasi kedalaman perairan ditunjukkan dengan kontur warna. Nilai kedalaman yang dihasilkan memiliki nilai kedalaman positif dari 0 meter sampai dengan $\mathbf{4 0 0 0}$ meter sesuai dengan kebutuhan software. Area terdalam dalam perairan merupakan wilayah laut lepas dengan nilai kedalaman antara 2000 meter sampai dengan 4000 meter yang ditunjukkan dengan gradasi kontur berwarna merah. Sedangkan pada area pesisir nilai kedalaman berkisar antara 0 meter sampai dengan 2000 meter yang ditunjukkan dengan gradasi kontur berwarna biru tua.

\section{Analisa Model Hidrodinamika}

Model hidrodinamika menggunakan software opensource Delft 3D dengan struktur grid. Pemodelan ini bersifat barotropik, dimana perubahan suhu dan salinitas diabaikan. Simulasi pemodelan ini dilakukan pada bulan Februari dengan lama simulasi 28 hari dan bulan Oktober dengan lama simulasi selama 31 hari. Hal ini dilakukan atas dasar pernytaan Badan Meteorologi Klimatologi dan Geofisika (BMKG) pada koran Republika, dimana musim hujan tahun 2017 secara umum mulai terjadi pada akhir Oktober hingga November dan puncak musim hujan akan diprediksi terjadi pada Desember 2017 hingga Februari 2018 (Republika 2017). Parameter yang digunakan dalam pemodelan hidrodinamika adalah sebagai berikut.

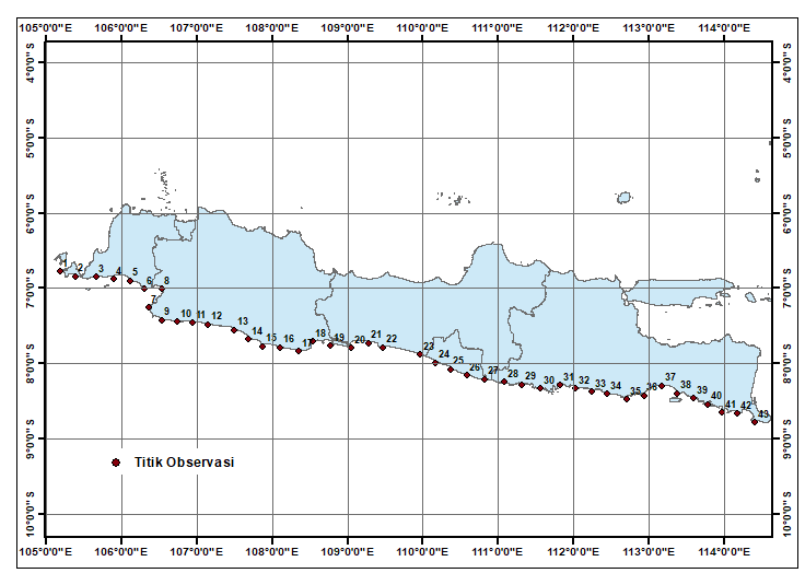

Gambar 6. Sebaran Titik Observasi

Lama simulasi pada bulan Februari 2017 adalah 28 hari dengan interval timestep 0,01 menit yang mengasilkan 1343 timestep. Simulasi dimulai pada tanggal 01 Februari 2017 00:00:00 hingga 28 Februari 2017 23:00:00. Bulan Oktober
2017 memiliki interval timestep yang sama untuk pemodelan selama 31 hari dan menghasilkan 1487 timestep. Pemodelan bulan Oktober dimulai dari tanggal 01 Oktober 2017 00:00:00 hingga 31 Oktober 2017 23:00:00. Simulasi model ini menggunakan 43 titik observasi tersebar di sepanjang garis pantai, seperti pada Gambar 6 .

Parameter lain didefinisikan menggunakan nilai yang diperoleh dari penelitian sebelumnya, website video pengenalan software Delft3D https://oss.deltares.nl/web/delft3d/screen-casts, atau default dari software pengolah dikarenakan data yang diperoleh sangat terbatas keterbatasan data pada lokasi penelitian.

\section{Analisa Pasang Surut}

Data pengamatan pasang surut yang digunakan dalam pemodelan hidrodinamika ini adalah data pengamatan dari 10 stasiun pasang surut BIG di kawasan pantai selatan Pulau Jawa pada tanggal 01 Februari 2017 01:00:00 sampai dengan 28 Februari 2017 23:00:00 dan 01 Oktober 2017 01:00:00 sampai dengan 31 Oktober 2017 23:00:00. Data ini memiliki interval 1 jam sehingga menghasilkan data bacaan sebanyak 671 untuk bulan Februari dan 743 untuk bulan Oktober. Lokasi koordinat setiap stasiun ditunjukkan pada Gambar 7.

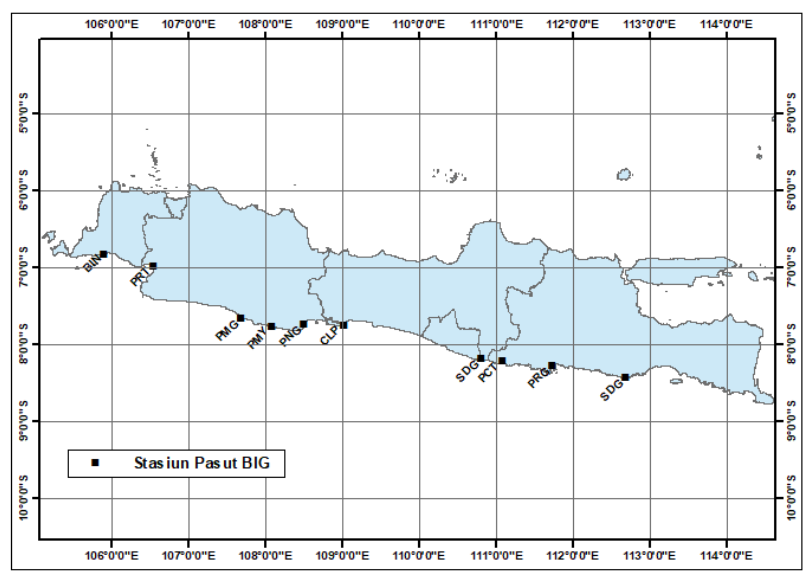

Gambar 7. Lokasi 10 Stasiun Pasut BIG

Analisa nilai pasang surut model dengan nilai pasang surut pengamatan dilakukan dengan perhitungan nilai RMSE dan MAE. Perhitungan nilai RMSE menghasilkan nilai rata-rata RMSE pada bulan Februari sebesar 0,273 m sedangkan nilai RMSE pada bulan Oktober sebesar 0,175 m. Nilai MAE menghasilkan nilai rata-rata MAE pada bulan Februari sebesar 0,219 m sedangkan nilai MAE pada bulan Oktober sebesar 0,134 m. Nilai RMSE dan MAE terkecil bulan Februari dan bulan Oktober 
berada pada stasiun Binuangeun dengan masingmasing nilai 0,087 dan 0,030 untuk RMSE; 0,063 dan 0,017 m untuk MAE
Hasil plot nilai stasiun pasang surut Binuageun dari observasi dan pemodelan ditunjukkan pada Gambar 8 berikut.
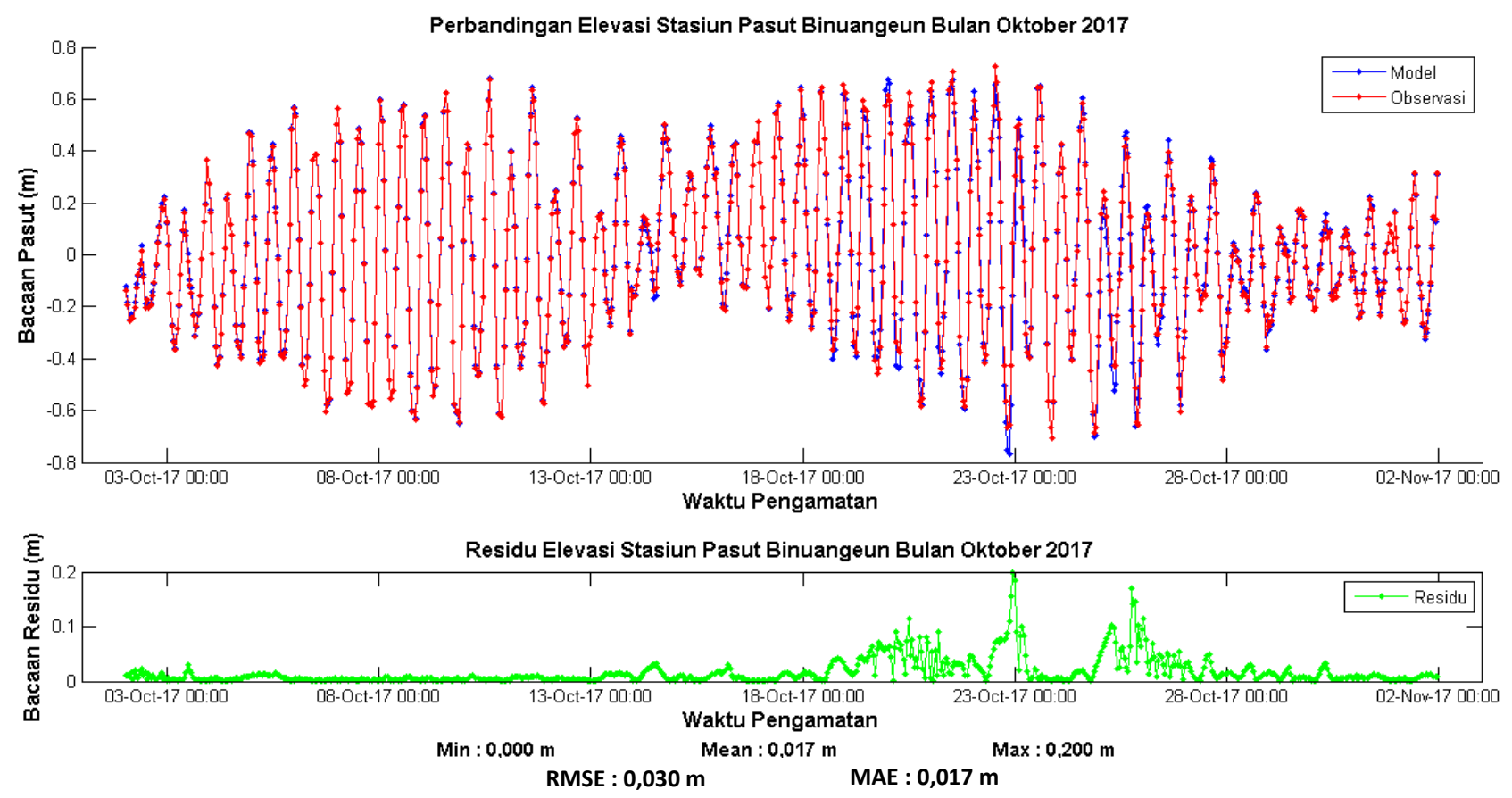

Gambar 8. Analisa Pasut Binuangeun Bulan Oktober 2017

Rata-rata yang dihasilkan dari kedua nilai RMSE dan MAE pemodelan bulan Februari dan Oktober memiliki nilai yang terdapat dalam rentang 0,00 hingga $0,299 \mathrm{~m}$ dengan tingkat kesalahan kecil (Khotimah 2012). Semakin kecil nilai kesalahan (error) yang dihasilkan menyatakan semakin dekat nilai pemodelan dengan nilai sebenarnya (Darmawan 2005). Dengan demikian dapat diketahui keakuratan dari algoritma pemodelan yang digunakan. Semakin rendah MAE semakin baik hasil yang diperoleh (Kurniati 2016).

\section{Analisa Energi Pasang Surut}

Energi pasang surut merupakan bentuk energi dengan memanfaatkan beda ketinggian pada waktu air laut pasang dan air laut surut. Energi pasang surut kemudian dapat diestimasi menggunakan formula yang disederhanakan menjadi sebagai berikut (Charlier 2009):

$$
P=225 \mathrm{AH}
$$

$P \quad$ : Daya listrik yang dihasilkan (kW)

$A$ : Luas permukaan wilayah pasang surut $\left(\mathrm{km}^{2}\right)$

$H \quad$ : Rentang pasut $(\mathrm{m})$

Luas permukaan wilayah pasang surut adalah selebar $35 \mathrm{~km}$ dari garis pantai terluar ke arah laut lepas dengan segmentasi $20 \mathrm{~km}$ sepanjang garis pantai, sehingga $A$ bernilai 700 $\mathrm{km}^{2}$.

Rata-rata energi listrik yang dihasilkan tipe pasang surut bulan Februari adalah sebesar $560468,327 \mathrm{~kW}$ dengan nilai terkecil 212435,055 kW di titik $105,186802^{\circ}$ BT $6,780582^{\circ}$ LS dan nilai

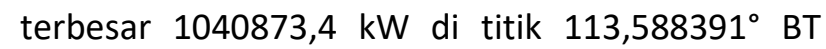
$8,465352^{\circ}$ LS. Rata-rata energi listrik yang dihasilkan tipe pasang surut bulan Oktober adalah sebesar 373867,1891 kW dengan nilai terkecil $227332,193 \mathrm{~kW}$ di titik $105,186802^{\circ}$ BT $6,780582^{\circ}$ LS dan nilai terbesar 520482,375 kW di titik $111,815020^{\circ}$ BT $8,288190^{\circ}$ LS.

dimana, 


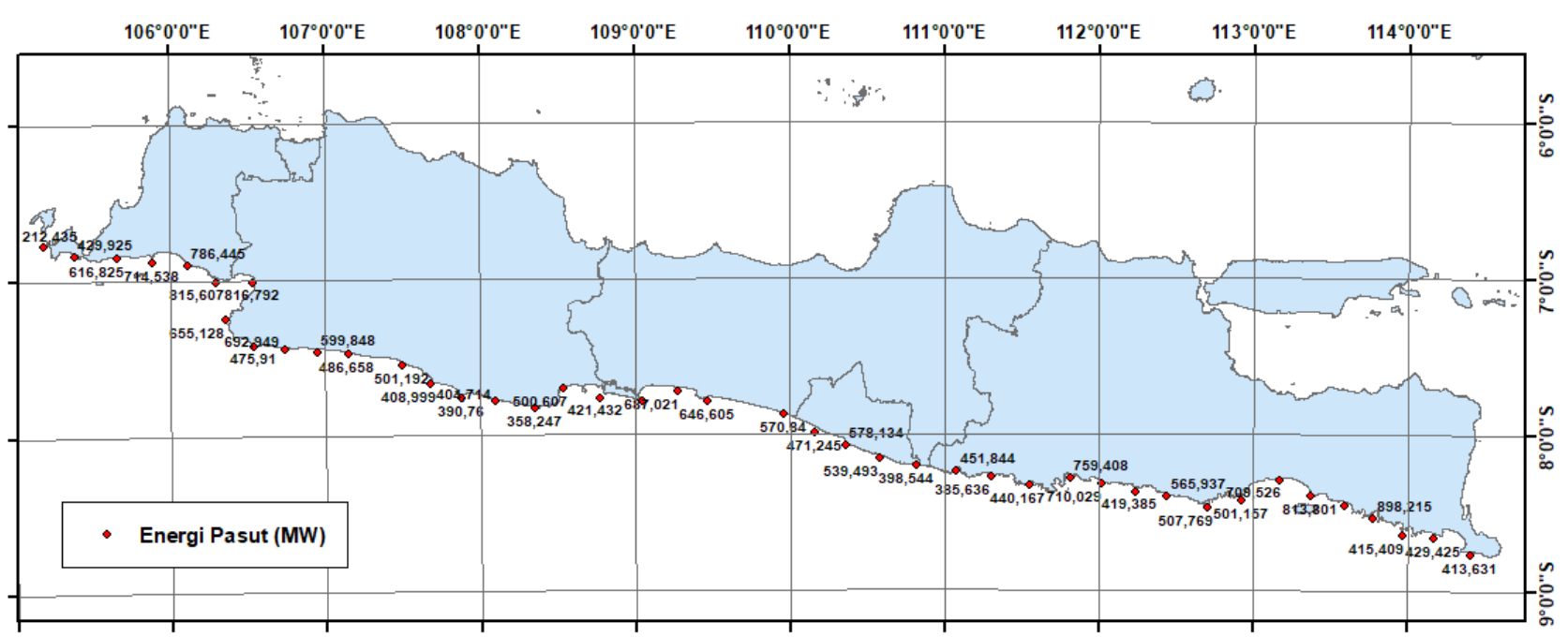

Gambar 9. Estimasi Energi Pasang Surut Bulan Februari 2017

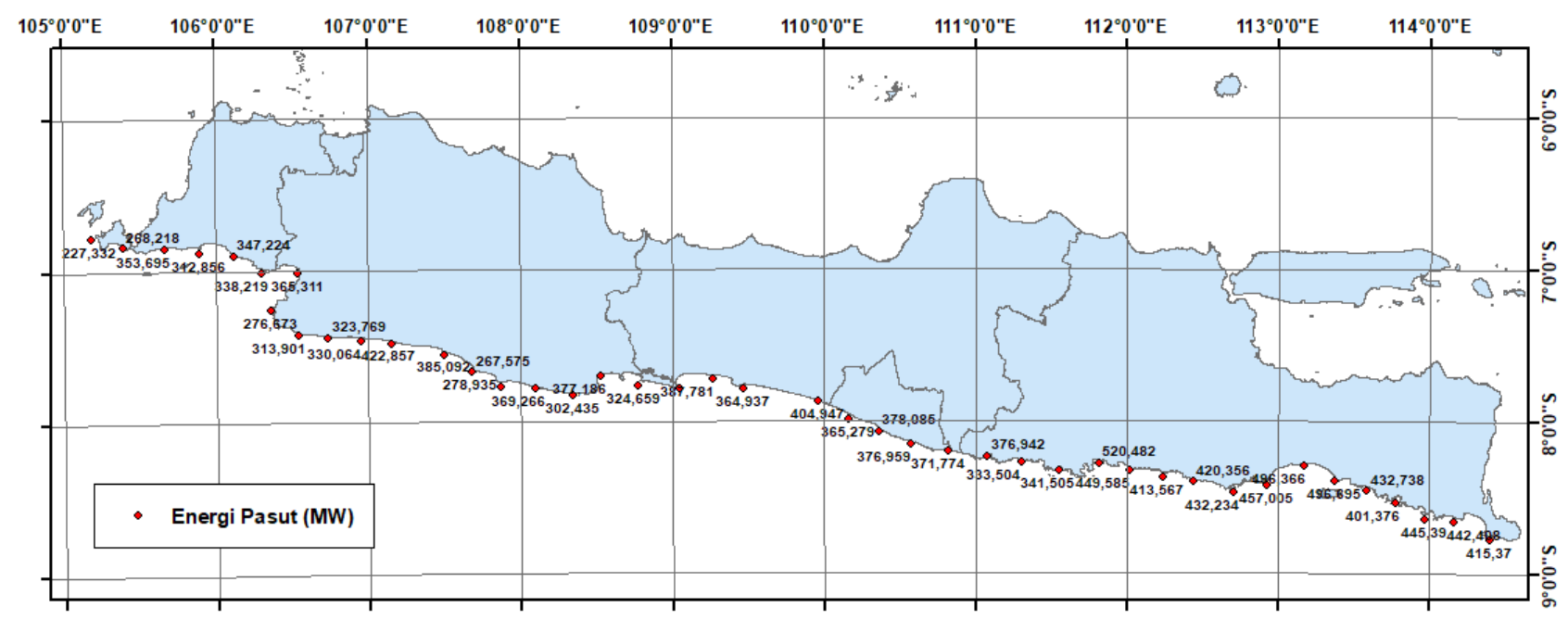

Gambar 10. Estimasi Energi Pasang Surut Bulan Oktober 2017

\section{Analisa Energi Arus Laut}

Konversi energi arus laut menjadi energi listrik pada umumnya menggunakan turbin sebagai penghasil energi kinetik yang kemudian ditransformasikan menjadi energi listrik melalui generator yang kemudian disimpan. Arus laut yang digunakan untuk memutar turbin merupakan arus laut permukaan dengan kedalaman antara 2-20 meter. Nilai minimum kecepatan arus yang dapat digunakan adalah 0,5 $\mathrm{m} /$ detik. Saat ini inovasi terbaru sedang dibuat dan dikembangkan oleh PT. T-Files Indonesia yang menggunakan turbin jenis helix (spiral) yaitu Gorlov Helical Turbine. Arus permukaan laut kemudian dikonversi menggunakan Persamaan Fraenkel dari karakter turbin T-Files (Yuningsih dkk., 2010) :

$$
P=\frac{1}{2} \times \rho \times v^{3} \times A \times \eta
$$

$P \quad$ : Daya listrik yang dihasilkan (W)

$\rho \quad: \quad$ Berat jenis air laut $\left(1207 \mathrm{~kg} / \mathrm{m}^{3}\right)$

V : Kecepatan arus (m/s)

A : Luas permukaan turbin $=$ ketinggian turbin $x$ diameter turbin $=1,2 \mathrm{~m}^{2}$

$\eta \quad$ : Koefisien generator $(79,07 \%)$

Rata-rata energi listrik yang dihasilkan tipe arus laut bulan Februari adalah sebesar 0,383 kW dengan nilai terkecil $0,000 \mathrm{~kW}$ di titik $106,532658^{\circ}$ BT 7,013790 LS dan $111,551586^{\circ}$ BT 8,332347 LS. Nilai terbesar energi yag dihasilkan adalah 9,319 kW di titik $106,357955^{\circ}$ BT 7,256966 ${ }^{\circ}$ LS. Rata-rata energi listrik yang dihasilkan tipe arus laut bulan Oktober adalah sebesar $0,059 \mathrm{~kW}$ dengan nilai terkecil 0,000 kW di titik 106,532658 ${ }^{\circ}$ BT 7,013790 LS dan $111,551586^{\circ}$ BT $8,332347^{\circ}$ LS. Nilai terbesar energi yag dihasilkan adalah $0,747 \mathrm{~kW}$ di titik di titik $106,357955^{\circ}$ BT $7,256966^{\circ}$ LS.

dimana, 


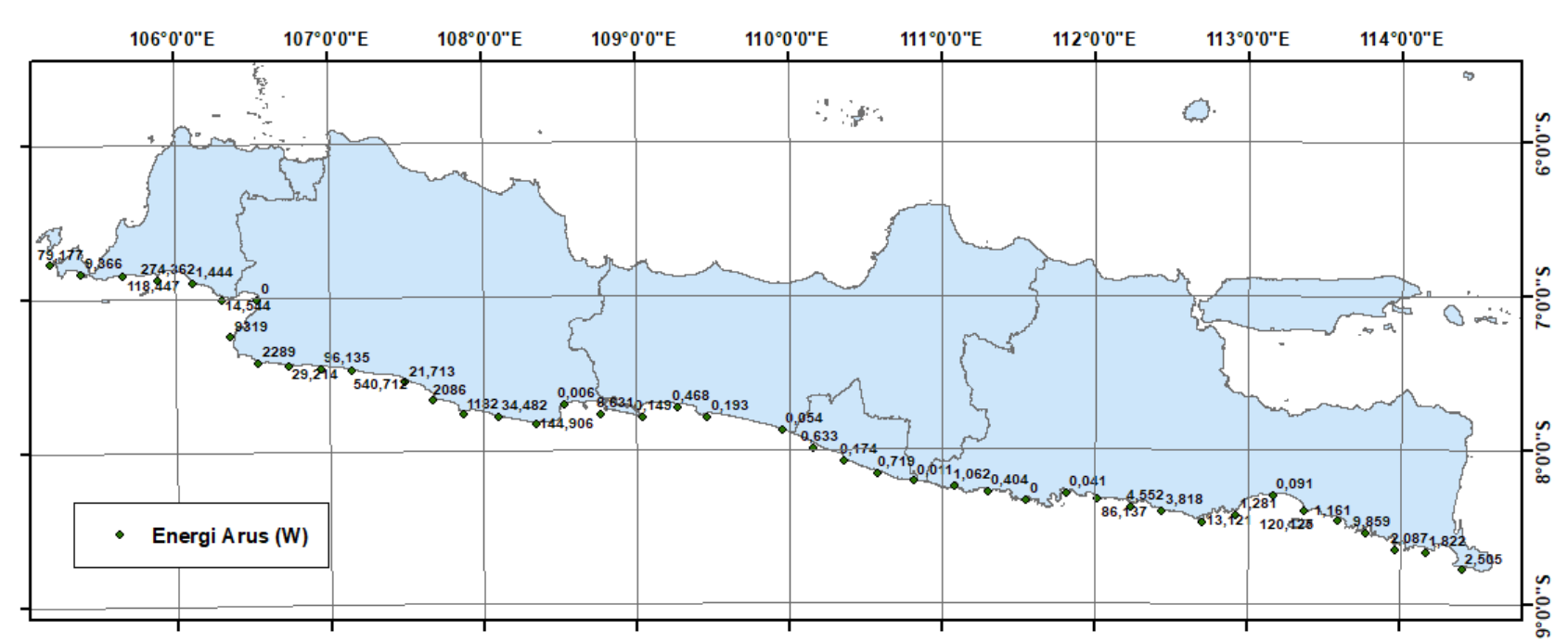

Gambar 11. Estimasi Energi Arus Laut Bulan Februari 2017

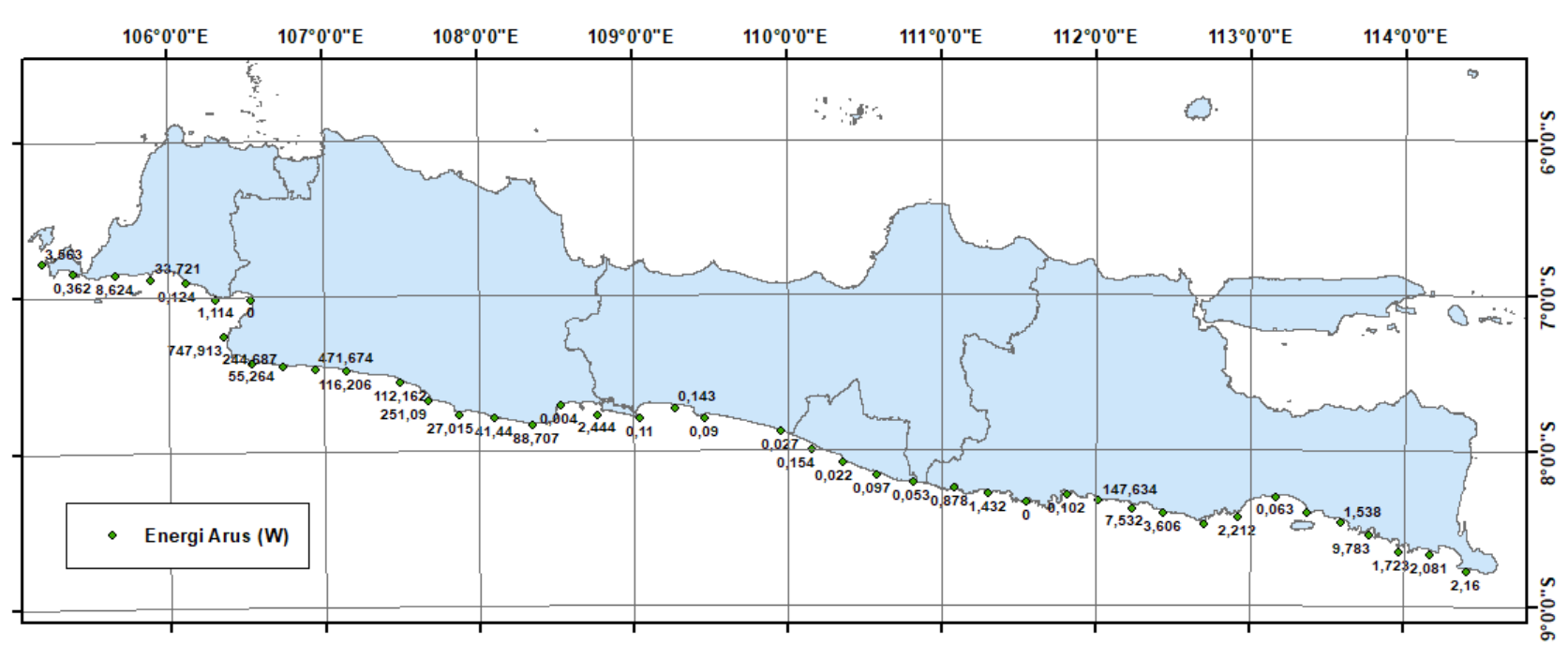

Gambar 12. Estimasi Energi Arus Laut Bulan Oktober 2017

\section{Analisa Energi Gelombang Laut}

Gelombang laut adalah pergerakan naik dan turunnya air laut dengan arah tegak lurus pemukaan air laut yang membentuk kurva/grafik sinusoidal. Konsistensi tinggi gelombang yang dihasilkan di perairan Selatan Jawa dikarenakan lokasi perairan yang berhadapan langsung dengan laut lepas (Samudera Hindia). Nilai minimum ketinggian gelombang yang dapat dimanfaatkan sebagai pembangkit listrik alternatif adalah sebesar 1,6 m (Cruz 2008), namun dengan nilai tinggi gelombang yang cukup besar dan konstan di perairan Selatan Jawa diharapkan energi listrik yang dihasilkan nanti cenderung stabil (Sriartha dan Putra 2015). Persamaan yang digunakan dalam penelitian ini berasal dari persamaan umum energi gelombang (Cruz 2008):

$$
E=c \times H^{2} \times T
$$

dimana,

E : Daya listrik yang dihasilkan per satuan luas $(\mathrm{kW} / \mathrm{m})$

c : Konstanta yang didapat dari $\rho g^{2} / 4 \pi$ (气7,87 $\mathrm{kW} / \mathrm{m}^{\mathrm{a}} \mathrm{s}$ )

$H \quad$ : Tinggi gelombang $(\mathrm{m})$

$\mathrm{T}$ : Periode gelombang (detik)

Rata-rata energi listrik yang dihasilkan tipe gelombang laut bulan Februari adalah sebesar $2,200 \mathrm{~kW} / \mathrm{m}$ dengan nilai terkecil $0,416 \mathrm{~kW} / \mathrm{m}^{2} \mathrm{di}$ titik $111,078271^{\circ}$ BT $8,240568^{\circ}$ LS. Nilai terbesar energi yag dihasilkan adalah $7,175 \mathrm{~kW} / \mathrm{m}$ di titik $105,186802^{\circ}$ BT $6,780582^{\circ}$ LS. Rata-rata energi listrik yang dihasilkan tipe gelombang laut bulan Oktober adalah sebesar $1,207 \mathrm{~kW} / \mathrm{m}^{2}$ dengan nilai terkecil $0,173 \mathrm{~kW} / \mathrm{m}$ di titik $106,532658^{\circ}$ BT $7,013790^{\circ}$ LS. Nilai terbesar energi yag dihasilkan 
adalah $3,241 \mathrm{~kW} / \mathrm{m}$ di titik $106,538753^{\circ}$ BT

$7,422939^{\circ}$ LS.

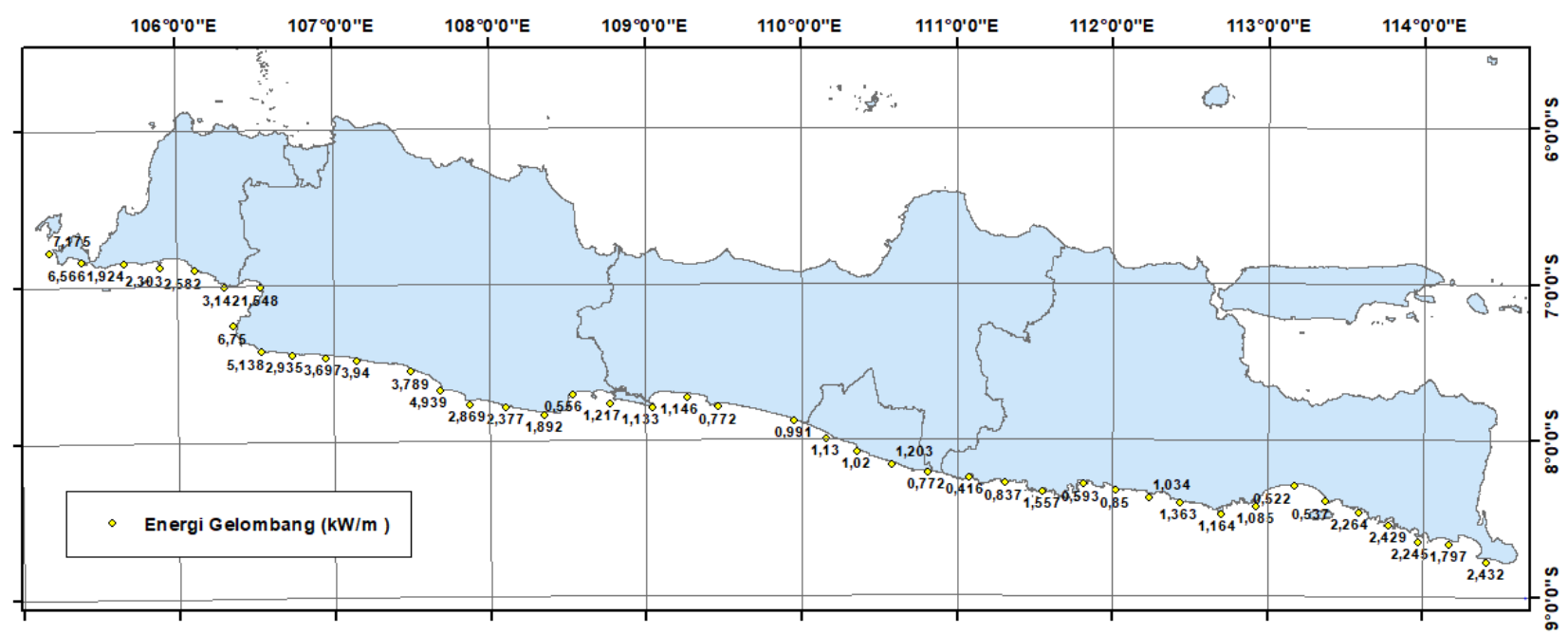

Gambar 13. Estimasi Energi Gelombang Laut Bulan Februari 2017

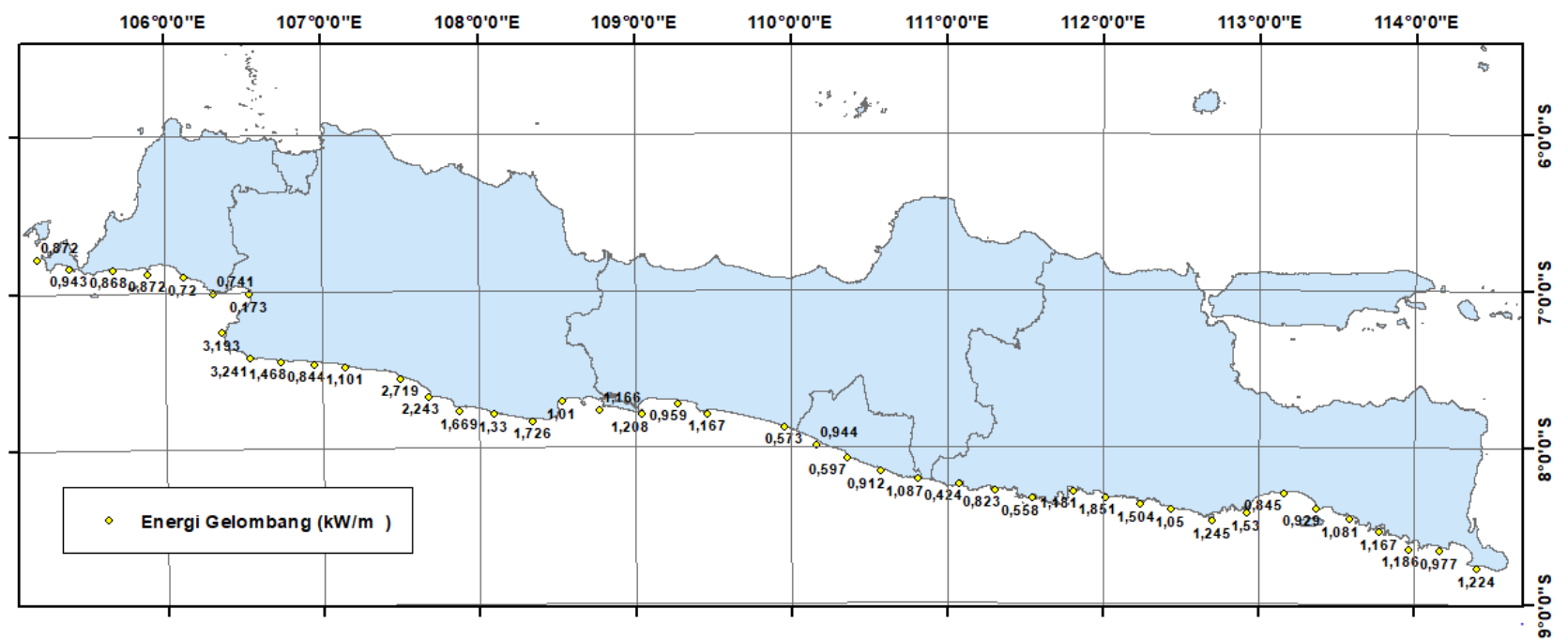

Gambar 14. Estimasi Energi Gelombang Laut Bulan Oktober 2017

\section{Analisa Lokasi Potensial}

Lokasi di pantai selatan Pulau Jawa memiliki potensi energi laut apabila memenuhi nilai minimum masing-masing parameter tipe energi sebagai berikut :

Tabel 1. Nilai minimum energi laut untuk pembangkit listrik (Purba dkk. 2014)

\begin{tabular}{|l|c|}
\hline \multicolumn{1}{|c|}{ Tipe Energi Laut } & Nilai Minimum \\
\hline Rentang pasang surut & $2,0 \mathrm{~m}$ \\
\hline Kecepatan arus & $0,5 \mathrm{~m} / \mathrm{s}$ \\
\hline Ketinggian gelombang & $1,6 \mathrm{~m}$ \\
\hline \multicolumn{2}{|c|}{ Sehingga dari } \\
\hline
\end{tabular}

diketahui lokasi potensial masing-masing tipe energi. Titik-titik observasi kemudian menjadi titik potensial jika memiliki akses jalan berjarak maksimal $5 \mathrm{~km}$ dari titik, agar kedepannya wilayah tersebut dapat lebih mudah dijangkau (Cahyani 2015). Hasil analisis menunjukkan pesisir selatan Pulau Jawa tidak memiliki potensi energi gelombang laut dikarenakan ketinggian gelombang yang dihasilkan pada bulan Februari dan Oktober di 43 titik observasi bernilai kurang dari 1,6 m. Namun, potensi energi pasang surut menghasilkan energi yang lebih besar dan lebih merata di sepanjang pesisir dibandingkan dengan potensi energi arus laut. Gambar 9 merupakan persebaran 19 titik potensial energi laut di pesisir selatan Pulau Jawa. Terdapat 2 titik di Provinsi Banten bagian selatan Kota Cihara dan Kota Bajah, Kabupaten Pandeglang. Provinsi Jawa Barat memiliki 10 titik tersebar di dekat kota Pelabuhanratu, Cibungur, Cibintaro, Sindangbarang, Pameungpeuk, 
Karanganyar, Kalapagenep, dan Sijilang. Bagian selatan Kota Binangun, Pagutan, dan Patutrejo memiliki 3 titik yang tersebar sepanjang pesisir Provinsi Jawa Tengah. Provinsi D. I. Yogyakarta di bagian selatan Kota Glagah memiliki 1 titik. Terdapat 3 titik di pesisir Provinsi Jawa Timur, salah satunya di selatan Kota Kedungkaji.

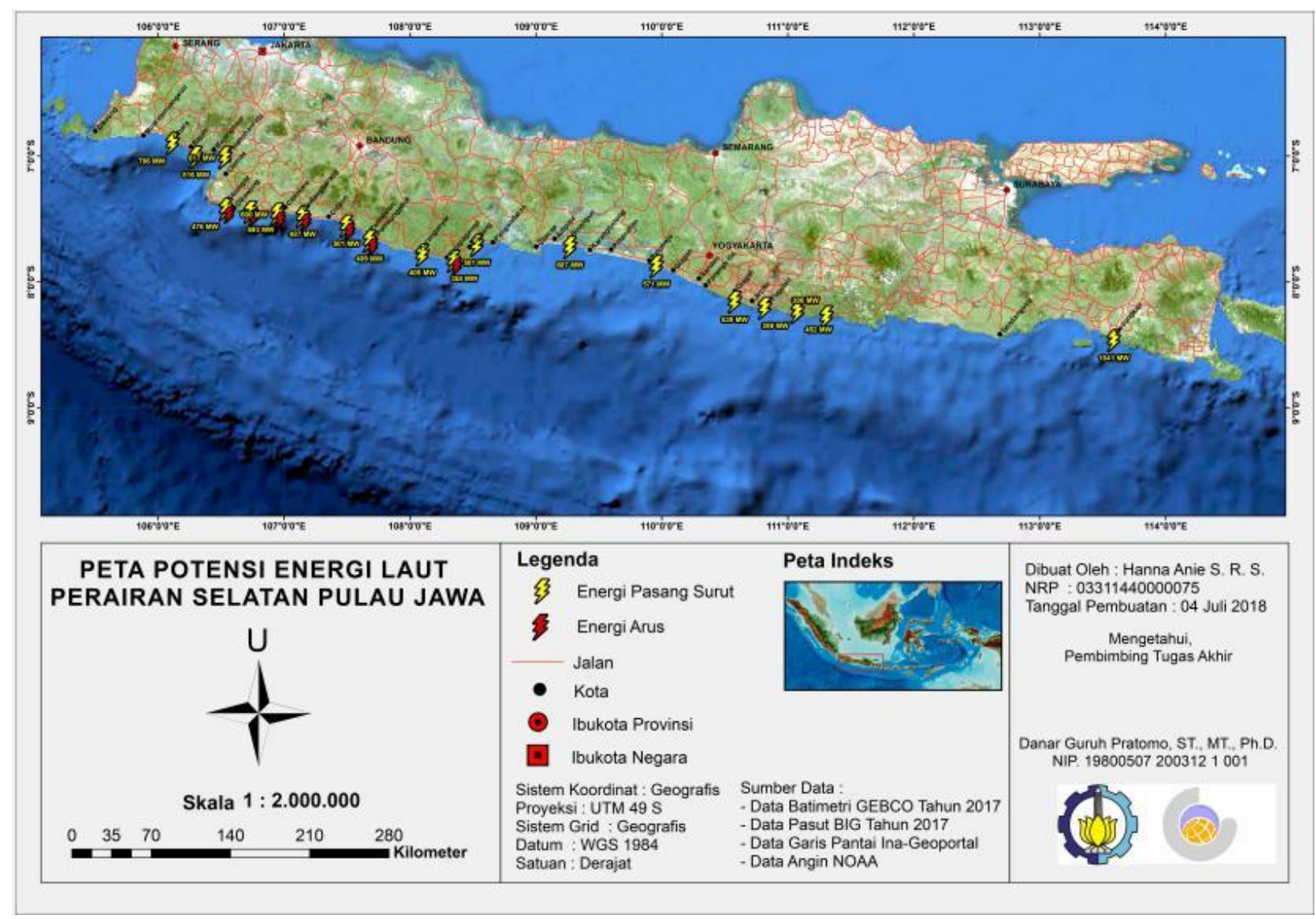

Gambar 15. Peta Persebaran 19 Titik Potensial Energi Laut

\section{KESIMPULAN}

Dari penelitian tentang pemetaan awal potensi energi laut yang dilakukan di pantai selatan Pulau Jawa menggunakan model hidrodinamika 3D menghasilkan beberapa kesimpulan sebagai berikut:

1. Pantai selatan Pulau Jawa tidak memiliki potensi energi gelombang laut dikarenakan rata-rata ketinggian gelombang pada bulan Februari hanya mencapai 0,221 $\mathrm{m}$ dan 0,170 $\mathrm{m}$ pada bulan Oktober, dimana keduanya tidak memenuhi nilai minimum yang dibutuhkan sebesar 1,6 m. Namun, potensi energi pasang surut menghasilkan energi yang lebih besar dan lebih merata di sepanjang pesisir dibandingkan dengan potensi energi arus laut. Rata-rata rentang pasut terbukti mencapai 3,558 $\mathrm{m}$ pada bulan
Februari dan 2,373 m pada bulan Oktober, sedangkan rata-rata kecepatan arus hanya mencapai $0,389 \mathrm{~m} / \mathrm{s}$ pada bulan Februari dan $0,269 \mathrm{~m} / \mathrm{s}$ pada bulan Oktober.

2. Terdapat 19 titik potensi energi laut di pantai selatan Pulau Jawa ditinjau dari akses jalan ke sekitar wilayah pesisir titik tersebut. Provinsi Banten terdapat 2 titik di bagian selatan Kota Cihara dan Kota Bajah. Provinsi Jawa Barat terdapat 10 titik tersebar di dekat kota Pelabuhanratu, Cibungur, Cibintaro, Sindangbarang, Pameungpeuk, Karanganyar, Kalapagenep, dan Sijilang. Provinsi Jawa Tengah terdapat 3 titik di bagian selatan Kota Binangun, Pagutan, dan Patutrejo. Provinsi D. I. Yogyakarta terdapat 1 titik di bagian selatan Kota Glagah. Terakhir, Provinsi Jawa Timur 
terdapat 3 titik, salah satunya di selatan Kota Kedungkaji.

3. Nilai rata-rata estimasi energi pasang surut yang dihasilkan pada bulan Februari dan Oktober masing-masing sebesar 560468,327 kW dan 373867,1891 kW. Estimasi energi terbesar bulan Februari mencapai 1040873,4 kW pada titik $113,588391^{\circ}$ BT $8,465352^{\circ}$ LS, sedangkan pada bulan Oktober mencapai $496365,975 \mathrm{~kW}$ pada titik $113,169822^{\circ}$ BT $8,296754^{\circ} \mathrm{LS}$.

\section{UCAPAN TERIMA KASIH}

Penulis mengucapkan terima kasih kepada Badan Informasi Geospasial (BIG) dan Badan Meteorologi, Klimatologi, dan Geofisika (BMKG) yang telah menyediakan data. Serta, Deltares Forum yang menjadi tempat diskusi dalam pengerjaan penelitian ini.

\section{DAFTAR PUSTAKA}

Charlier, RH. \& Finkl CW. (2009). Ocean energi : tide and tidal power. Berlin: Springer. Page 38-39.

Cruz, J.. (2008). Ocean wave energy: current status and future perspecgives. Heidelberg: Springer. Page 220-241.

Darmawan, A., Riko Arlando Saragih. (2005). Pengkodean Video dengan Metode Spatial Scalability. Seminar Nasional Aplikasi Teknologi Informasi : 7-12.

DESDM. (2005). Diversifikasi Energi, Energi Kelautan sebagai Alternatif Baru. DESDM (disampaikan pada Seminar Pembangunan Ekonomi Kemaritiman 15 Maret 2005), Jakarta.

Khotimah, Mia Khusnul. (2012). Validasi Tinggi Gelombang Signifikan Model Gelombang WindWave-5 dengan Menggunakan Hasil Pengamatan Satelit Altimetri Multimisi. Tesis, Fakultas Matematika dan IImu Pengetahuan Alam, Program Pasca Sarjana, Program Studi Magister IImu Kelautan, Universitas Indonesia, Depok.
Kurniati, Junia. (2016). Identifikasi Tanda Tangan menggunakan Transformasi Gabor Wavelet dan Jarak Minkowski. Annual Research Seminar. Vol. 2, 1: 363-368.

Muktashor. (2011). Potensi Listrik Tenaga Laut Indonesia Capai $727.000 \quad$ MW. https://finance.detik.com/energi/1684601/pot ensi-listrik-tenaga-laut-indonesia-capai727000-mw. Diakses pada 24 Januari 2018.

Purba, Noir P. (2014). Variabilitas Angin dan Gelombang Laut Sebagai Energi Terbarukan di Pantai Selatan Jawa Barat. Jurnal Akuatika Vol. 1, 1 : 815.

Purba, Noir P., Jaya Kelvin, Rona Sondra, Syahrir Gibran, Resti A. I. Permata, Fatimah Maulida, Marine K. Martasuganda. (2014). Suitable Locations Of Ocean Renewable Energi (ORE) In Indonesia Region - GIS Approached. Conference and Exhibition Indonesia - New, Renewable Energy and Energi Conservation.

Republika. (2017). BMKG: Waspadai Curah Hujan Ekstrem pada Desember 2017. http://nasional,republika,co,id/berita/nasional/ umum/17/11/24/ozvz6r354-bmkg-waspadaicurah-hujan-ekstrim-pada-desember-2017. diakses pada 21 Mei 2017.

Sriartha, I.P., Putra, I.W.K.E., (2015). Distribusi Spasial Genangan Air Laut Berdasarkan Analisis Data Satelit Altimetri Envisat di Wilayah Pesisir Barat Kabupaten Buleleng, Bali. Jurnal Bumi Lestari Vol. 15, 2:165- 175.

Sutrisno, A. Dwi., Ag. Isjudarto. (2016). Akurasi Konturing Trianggulasi Dan Kriging Pada Surfer Untuk Batubara. Prosiding Seminar Nasional XI "Rekayasa Teknologi Industri dan Informasi. Sekolah Tinggi Teknologi Nasional Yogyakarta :185-189.

Yuningsih A., Sudjono EH., Rachmat B., Lubis S. (2010). Prospek Energi Arus Laut di Perairan Indonesia. Balitbang ESDM. 